metically sealed, and after a lapse of time on opening the vessel the organisms were found in a living state, they must have arisen de novo. That is, the not living would have produced the living ; that this method is useful, and that it must be pursued in an exhaustive inquiry into the whole subject, must be freely admitted. But that it is the best, or at least the only, method of inquiry for the biologist we may gravely doubt.

Ten years ago Mr. Dallinger determined to endeavour to work out by actual microscopic observation the life history of some of the lowly life forms.

After four years spent in preparation he commenced his work in conjunction with Dr. Drysdale, the plan needing two observers. A characteristic feature of the work was that each set of observations should be made absolutely continuous, so that nothing should have to be inferred. An arrangement was made by which the little drop of septic fluid cortaining the objects under examination should be free from evaporation, and very high powers were employed. The largest adult objects included in the examination were the one-thous andth of an inch, the smallest adults were the four-thousandth. Six forms altogether were selected, and, by long, patient, and unbroken watching, their whole history was worked out. While reproduction by fission seemed at first to the observers to be the usual method, prolonger research made knnwn that spores were produced. These were so small that a m inifying power of 5,000 dianeters was needed to see them as they began to grow. The glairy fluid from which they developed seemed at hist homogeneous, and it was only when growth set in that the spores became visible. All that could be learnt about the origin of the glairy fluid was that a monad, larger than usual, and with a granulated aspect towards the flagellate end, would seize on one in the ordinary condition. The two would swim about together till the larger absorbed the smaller, and the two were fused together. A mo. tionless spheroidal glossy speck was then all that could be seen. This speck was found to be a sac, and after remaining still for from ten to thirty-six hours it burst, and the glairy homogeneous fluid flowed out. The young spores that came into view in this were watched through to the adult condition. Bearing on the subject of spontaneous generation, this fact was learnt, that while a temperature of $140^{\circ} \mathrm{F}$. was sufficient to cause the death of adults, the spores were able to grow even after having been heated to $300^{\circ} \mathrm{F}$. for ten minules. Can it be philosophical, Mr. Dallinger asked, with the life history of bacteria still unknown, to assume it as a different method of propagation? Some experiments based on Prof. Tyndall's use of the electric beam to test optica ally pure air were made. The remains of infusions known to contain certain spores were diffused through glass tubes, in which were placed vessels with fluid. Monads always appeared in the fluids, but when after the air in the tubes had been allowed to purify itself by settlement, fresh fluids were introduced, no monads appeared. That there is no such thing as spontaneous generation of monads seems quite clear, and when bacteria are in like manner studied, there can be hardly a doubt the same law will be found to hold good with them.

\section{GREAT GUNS}

$T$ is natural that at the present time great interest should be taken in all efforts to improve, that is, to render more destructive, our implements of war. Even since the last war on the European field great advances have been made in this direction; and, as our readers know, one of the largest guns ever constructed is at present on its trial in this country. Some months ago experiments were made with what is known as the $8 \mathrm{I}$-ton gun, the invention of Mr. Robert Fraser; the gun was sent back to Woolwich for some alterations to be made, and on Friday the experiments were resumed at Shoeburyness on a larger scale. On the previous occasion the gun was loaded with 370 lbs. of powder, and threw a blind Palliser shell against the target. This target is of enormous strength, as strong and firmly founded as the ingenuity of engineers can make it. It is formed of four plates of the best rolled iron, each plate being 8 inches thick, and 5 inches of solid teak filled up each of the three intervals between the four plates. The 32 inches of iron and 15 inches of teak thus placed are solicliy screwed together by bolts 3 inches in diameter, the whole forming, as far as scientific engineers and artillerists could construct it, an apparently impenetrable and immovable mass. To secure the target still more, iron plates were placed on the top and at the side, those at the side being strutted against the target with heary timbers; and the supports at the rear of the target, to hold is up, as it were against any blow, were of the like solid and substantial character.

The target stood at r2o yards' distance from the gun. On Friday the charge of powder was $425 \mathrm{lbs}$, and the weight of the blind Palliser shell 1,700 1bs. At the base of the latter was an expanding copper-ridge, known as the "Lyon" gas-check, which in the explosion would expand and fill the rifling, thus enabling the full energy of the exploded powder to be utilised.

After the gun was fired, by electricity, it was examined and found to have worked admirably; it had run back 55 feet on its tramway, which rises slightly, and had run down again to the firing point. The shot was found not only to have penetrated three plates and the teak intervals to all four, as on the previous occasion, but to have bulged out the fourth plate some 15 inches from its normal position. The last plate was, moreover, broken across, the edges of the broken part gaping wide, and showing the head of the shot, which hat thus penetrated further in distance than the 47 inches of iron and teak of the targer. The powerful framework behind the target was greally shaken. The shot itself had "set-up," i.e., closed towards the head with the enormous energy, the rear-part, the gun-metal studs, and the copper gas-check, crumbling into pieces. The initial velocity of the shot, as registered by $M$. Le Boulenger's invention of wires with electric communication was $I, 600$ feet a second, and the striking velocity 5,585 teet. The mean pressure on the gun was found to be 20 tons, the interior remaining quite unaltered.

Herr Krupp, the well-known Prussian artillerist, has been devising a weapon even more formidable than that whose power of destruction was shown on Friday to be so immense, The Fraser gun is of wrought iron, but the new Krupp gun is of cast-steel, both being very nearly of the same weight, though the latter has the great advantage over the former of being a breech-loader. "The length of the gun, including the breech-picce, is 29 reet 6 inches, the breech-piece itself being 6 feet 4 inches in lenth. The calibre of the gun is 15 inches. The weight of the projectile will be 750 kilogrammes, or 1,650 lbs, and the powder charge will be 395 los. The external diameter of the Krupp gun, independentily of a narrow strengthening ring at the extreme rear, is 5 feet Io inches, that of the Fraser gun being 6 feet. The core of the Krupp gun is a steel tube in two lengths, upon which four steel rings overlap, rising in steps from a point between the muzzle and the trunnions, and accumulating in the thickness towards its rear. These more massive rings are irrespective of the narrow strengthening ring over the powder chamber. The external diameter of the gun at the muzle is 2 feet $3 \frac{1}{2}$ inches.

In common with the other large Krupp guns, the rifling of the new weapon is on the polygroove system, the elongated projectile being rotated by means of the gas-check. The velocity anticipated from the projectile tired from. the Krupp 8o-ton gun is 473 metres per second at the muzzle, or 1,552 feet, producing an energy of 27,543 foot tons, equal to 556 foot tons per inch of shot's circumference.

But this is not all. Should the demand arise, the great Prussian gun-maker has a design already prepared for a gun of 124 tons, to be made on the same plan as the one just described. The larger weapon would have a calibre slightly exceeding 18 inches, and would throw a steel shell weighing $\mathrm{I}, 000$ kilogrammes, or a chilled iron shell of 1,030 kilogrammes. 'The weight of the projectile would therefore be practically a ton, and the charge of powicr? will be probably about 500 pounds. 